\title{
EMIGRATION SENTIMENT AMONG STUDENTS IN THE CONTEXT OF THEIR CIVIC IDENTITY
}

\author{
INGA PETROVSKA, \\ Faculty of Philosophy, Department of Psychology \\ Ivan Franko Lviv National University, \\ Universytetska Str 1, Lviv, Ukraine \\ E-mail address: petrovin55@gmail.com
}

\begin{abstract}
This article presents the results of the study of students' emigration sentiment peculiarities in the context of their civic identity. Various types of the students' civic identity have been discovered, namely "protest", "uncertain", "patriotic". Protest and uncertain attitude to citizenship (potential emigrants) is associated with the level of psychological well-being of students, dissatisfaction with certain aspects of their life, especially professional and life prospects. Civil identification of students will acquire emotional and patriotic significance only if the state promotes socio-professional and personal fulfillment for the future experts.
\end{abstract}

Key words: identity, civic identity, students, emigration sentiment, personal fulfillment, patriotism, consciousness, unconscious.

\section{INTRODUCTION}

The future of the Ukrainian state depends largely on the existing Ukrainian civic identity. Loss of civic identity creates serious problems associated with deep alienation of society from the state, a sense of decay, instability of human life and may even pose a threat to national security. "Today, society is covered with civic identity crisis whose consequences affect in particular the possibility of government to promote citizens' mobilization and their consolidation for addressing strategic challenges", says Tetyana Bevz (2014, p. 4). It is identity that protects the state from expansion and absorption by other states, nations and cultures.

Today, there is an urgent need for a thorough study of civic identity as a psychological phenomenon as the individual experiences of his/her nationality, options for infilling its structure, etc. For conscious state affiliation does not mean the presence of civic identity.

Emigration of scientific, humanitarian and technical intelligentsia also presents serious obstacles to economic, social, cultural and political revival of the country. The emigration of young people, in particular students, which 
are the main source of Ukraine's intellectual development is of particular concern. This requires us to carefully study the emigration sentiment of the Ukrainian students, its role in the structure of personality and connection with the civic identity as identification with Ukraine not only based on the passport, but also its future.

Emigration sentiments can be regarded as a set of orientations and motives related to the desire to travel abroad for different purposes (Deyneko \& Golikov, 2012, p. 220). The biggest danger of intellectual exile is leaving for permanent residence, which serves not only as the change of residence, but also a deep process of change in lifestyle and the everyday practices and, most importantly, a sign of readiness of the Ukrainian students «to give up» their identity, replace it with some other identity which means that the Ukrainian lifestyle, Ukrainian values, social relations, etc become unimportant for them.

Scholars such as Miroslav Borishevsky (2001, pp. 39-46), Viktor Stepanenko (2002, pp. 102-120), Ludmila Snigur (2003, pp. 3-15), Nihora Khazratova (2004, pp. 3-13), Vadim Vasyutynskyi (2008, pp. 37- 44), Ludmila Sokuryanska (2008, pp. 520-525), Nataliya Savelyuk (2010, pp. 138-144), Alexander Stegniy (2011, pp. 50-72), Olga Rovenchak (2011, pp. 120-130), Vera Arbyenina (2012, pp. 39-71), Natalia Bezgina (2013, pp. 8-14), Tetyana Bevz (2014, pp. 4-16), and others were interested in Ukrainian civic consciousness (identity to a lesser extent). However, most scholars consider civic identity only as a rational construct without considering the fact that civic identity, in our opinion, is a complex multifaceted formation, only a part of which is recognized by a personality, i.e. it exists at the level of consciousness and the unconscious. Accordingly, we can assume the existence of contradictions in the conscious and unconscious perception of oneself as a citizen.

Civic identity is the most important mechanism of political socialization manifested in the individual identification with a certain public-political community. At the same time, civic identity, expressing humans' affiliation to a particular country and national environment, creates the awareness and sense of indivisibility with it while separating them from representatives of other state communities.

Civic identity as a form of social identity. Humans must necessarily correlate themselves with any system that would be channeling their lives in some direction and give meaning to their lives. Otherwise, the person may be filled with doubts that completely stifle his/her abilities, and hence life itself. The human lives due to belonging to society, a member of which he/she is (Erikson, E., Fromm, E., Turner, J. \& Tajfel, H., Abrams, D., etc.). Civic identity is most closely associated with the value-conceptual sphere of the individual, since the individual must determine the values inherent in this group, and most importantly, make a decision - whether he/she is ready to correspond to them identify themselves as belonging to a social group.

Thus, the civic identity is a dynamic formation constructed by the individual when comparing with others, considering values, filling with sense, finding a new place in the social environment. It is important to understand 
that the rational-cognitive stage of identification does not automatically lead to the individual's willingness to identify with the social community, belonging to which is the subject of reflection. The final decision mediated with emotionally evaluative attitude to it made under the influence of personal systems of values, assessments, feelings, emotions, etc.

Identity plays an important role in shaping emigration attitudes of young people because awareness of their own identity guarantees the placement of the individual in the space of social relations and, therefore, the decision as to staying in this space or moving to another one.

\section{THE INVESTIGATION PROCEDURE}

civic identity is considered by us as a complex multifaceted formation that embodies the identification of the individual with the community of citizens of a country and exists at the level of consciousness and the unconscious, including cognitive (knowledge of belonging to a given social community), value-emotional (positive, negative or ambivalent attitude to independence, its acceptance or rejection), behavioral (public stance in communication and activities, civic engagement, participation in social activities that have social significance) and image-semiotic (signs, symbols) components.

The aim of our study was to identify the relationship between the level of civil identity formation and emigration sentiments among the future experts and contradictions in the conscious and unconscious perception of oneself as a citizen of Ukraine.

Accordingly, the author has developed "Civic Identity" questionnaire based on the Likert Scale (Allen, \& Seaman, 2007, pp. 64-65). Questionnaire items are simple statements to be assessed by the respondent. Five points are used: 1 - completely disagree, 2 - rather disagree, 3 - hard to say, 4 - rather agree, 5 - completely agree. Statements were selected using expert evaluations (10 experts) and in the pilot study (including tasks discriminatory power and efficiency). The author has also developed 10 situations of projective nature (incidents) whose purpose is to identify unconscious aspects of civic identity of students and their emigration attitudes.

It was also important to explore the features of value-motivational sphere of students using the following methodologies: Schwartz Value Survey (1992) adapted by O. Tykhomandrytska (2001), Schein's Career Orientations Inventory (1990) adapted by V. Chiker (2000), Motivation to success by T. Ehlers adapted by V. Rozanova (1999), and determine their level of psychological well-being using K. Ryff's Scales of Psychological Well-being (1995) adapted by S. Karskanova (2011).

The study involved $1122^{\text {nd }}-5^{\text {th }}$ year students aged 18-24 years of Ivan Franko National University of Lviv (Faculties of Philosophy, Physics, Geography). Among them there were 60 women (53.6\%) and 52 men (46.4\%). The investigation was conducted in September - November 2015. 


\section{THE RESULTS OF THE RESEARCH}

The obtained results of the research, namely the percentage distribution of students by the questionnaire statements responses are presented in Table 1 .

Table 1. Respondents distribution (\%) based on their responses to the statements on Ukrainian civic identity

\begin{tabular}{|c|c|c|c|c|c|c|}
\hline No & Statement & 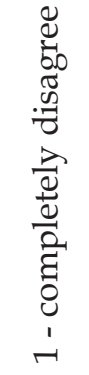 & 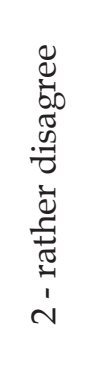 & 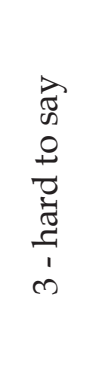 & 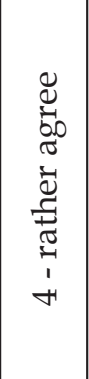 & 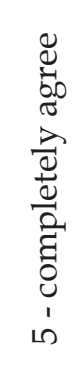 \\
\hline 1 & I am proud to be a citizen of Ukraine & 4.2 & 5.6 & 12.7 & 42.3 & 35.2 \\
\hline 2 & I always take part in the elections & 7.0 & 8.5 & 23.9 & 31.0 & 29.6 \\
\hline 3 & I consider myself to be a patriot of Ukraine & 5.6 & 8.5 & 39.4 & 28.6 & 11.3 \\
\hline 4 & I deeply respect state symbols of Ukraine & 5.6 & 8.5 & 16.9 & 31.0 & 38.0 \\
\hline 5 & I associate my future only with Ukraine & 14.1 & 19.7 & 39.4 & 22.5 & 4.2 \\
\hline 6 & $\begin{array}{l}\text { If I had the opportunity, I would unhesitatingly move } \\
\text { to another country }\end{array}$ & 7.0 & 16.9 & 33.8 & 22.5 & 19.7 \\
\hline 7 & $\begin{array}{l}\text { I believe in the prospects of Ukraine's development } \\
\text { as a state }\end{array}$ & 2.8 & 9.9 & 22.5 & 40.8 & 23.9 \\
\hline 8 & $\begin{array}{l}\text { There are a lot of opportunities for personal and } \\
\text { professional fulfillment in Ukraine }\end{array}$ & 14.1 & 23.9 & 28.2 & 22.5 & 11.3 \\
\hline 9 & $\begin{array}{l}\text { It is important to support Ukrainian traditions and } \\
\text { culture for me }\end{array}$ & 4.2 & 7.0 & 14.1 & 45.1 & 29.6 \\
\hline 10 & I am ready to work for Ukraine & 2.8 & 16.9 & 31.0 & 36.6 & 12.7 \\
\hline 11 & I totally identify myself as the citizen of Ukraine & 4.2 & 5.6 & 15.5 & 43.7 & 31.0 \\
\hline 12 & I consider myself to be a responsible citizen & 2.8 & 9.9 & 40.8 & 35.2 & 11.3 \\
\hline 13 & My idea of myself is closely related to Ukraine & 8.5 & 19.7 & 29.6 & 31.0 & 11.3 \\
\hline 14 & I always defend my rights as a citizen & 2.8 & 8.5 & 23.9 & 39.4 & 25.4 \\
\hline 15 & $\begin{array}{l}\text { I do not care in which country I will fulfill myself and } \\
\text { my talents }\end{array}$ & 31.0 & 26.8 & 21.1 & 12.7 & 8.5 \\
\hline 16 & I appreciate my civic activity & 16.9 & 29.6 & 29.6 & 18.3 & 5.6 \\
\hline 17 & I love Ukraine & 2.8 & 4.2 & 9.9 & 36.6 & 46.5 \\
\hline 18 & I consider myself to be a European & 2.8 & 5.6 & 23.9 & 35.2 & 32.4 \\
\hline 19 & I consider myself to be a citizen of the world & 5.6 & 12.7 & 16.9 & 36.6 & 28.2 \\
\hline 20 & I consider myself to be a Soviet person & 97.2 & 1.4 & 1.4 & 0 & 0 \\
\hline
\end{tabular}

Source: Own research

The conducted cluster analysis identified three groups of students with different types of civic identity 


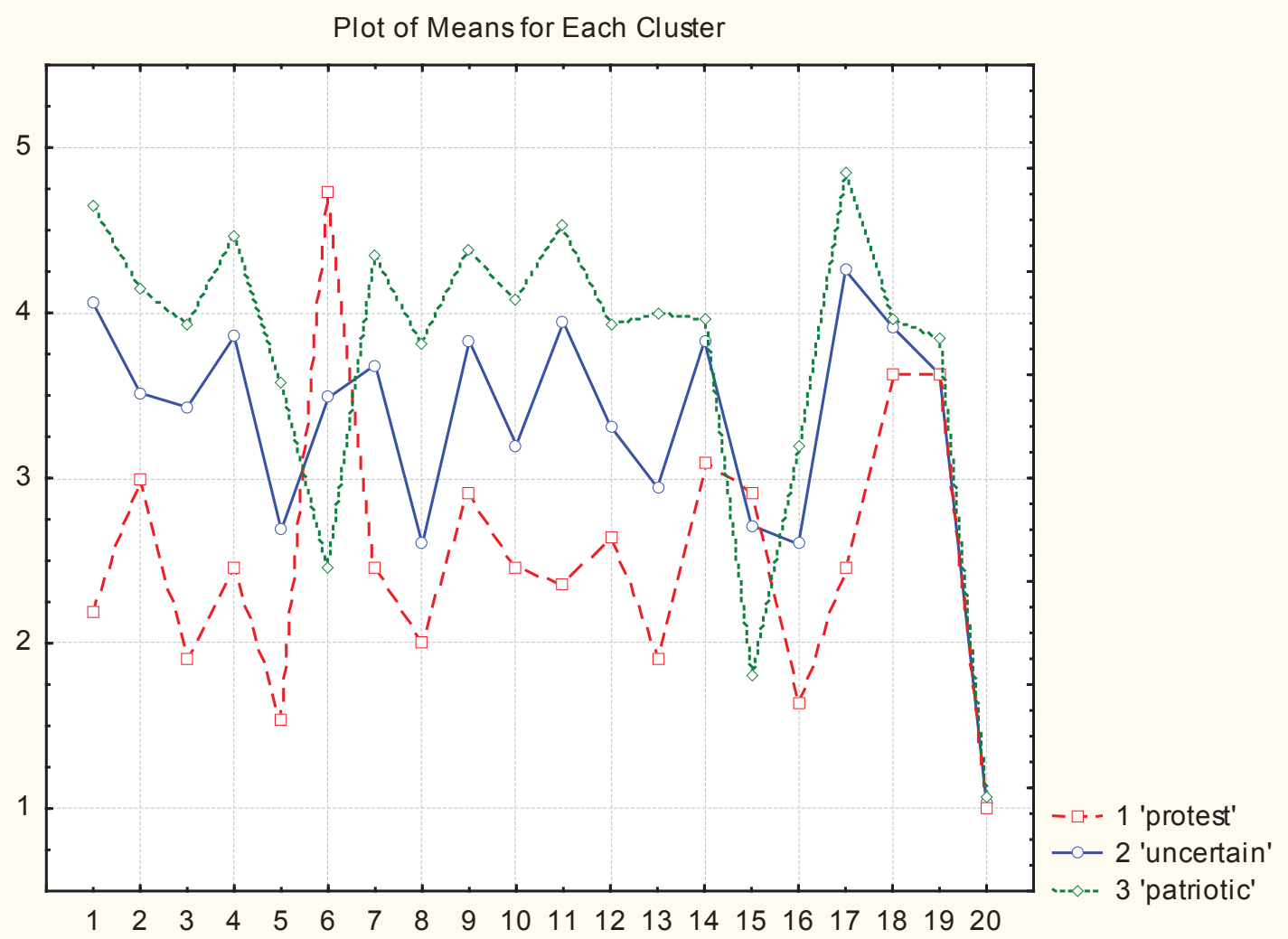

Fig. 1. Mean values of the civic identity parameters for different groups of students

1 - I am proud to be a citizen of Ukraine; 2 - I always take part in the elections; 3 - I consider myself to be a patriot of Ukraine; 4 - I deeply respect state symbols of Ukraine; 5 - I associate my future only with Ukraine; 6 - If I had the opportunity, I would unhesitatingly move to another country; 7 - I believe in the prospects of Ukraine's development as a state; 8 There are a lot of opportunities for personal and professional fulfillment in Ukraine; 9 - It is important to support Ukrainian traditions and culture for me; 10 - I am ready to work for Ukraine; 11 - I totally identify myself as the citizen of Ukraine; 12 - I consider myself to be a responsible citizen; 13 - My idea of myself is closely related to Ukraine; 14 - I always defend my rights as a citizen; 15 - I do not care in which country I will fulfill myself and my talents; 16 - I appreciate my civic activity; 17 - I love Ukraine; 18 - I consider myself to be a European; 19 - I consider myself to be a citizen of the world; 20 - I consider myself to be a Soviet person.

Source: Own research

Students of the first group (32.4\%) consciously demonstrate the protest rejection of Ukrainian civic identity: they are not very proud that they are citizens of Ukraine, rarely participate in elections, do not consider themselves patriots, are not planning to link their future only with Ukraine, almost do not believe in the prospects of Ukraine's development as a state, do not see the opportunity for personal and professional fulfillment in Ukraine, etc. It should be noted that $82 \%$ of the students of this group would unhesitatingly move to live in another country! This public stance can be called «stranger in a foreign country» or "protest" civic identity.

Students of the second group $(15.5 \%)$ show some inconsistency, uncertainty in their own identity as the citizens (they «hard to say» response to the 
majority of statements), however, they do not exclude loyalty to their country. This public stance can be called «neutral» or "uncertain". In this group, $49 \%$ of students answered "agree" and "rather agree" with the statement "If I had the opportunity, I would unhesitatingly move to another country". Analysis of the emigration sentiment among the Ukrainian students of this group suggests that for half of the students these sentiments do not serve as the manifestation of anti-patriotism and are caused primarily by the desire for self-fulfillment in the job, personal life, etc., but, unfortunately, they do not see such opportunities for themselves in Ukraine.

Students of the third group (52.1\%) demonstrated deep commitment to their country, the dominance of patriotic feelings and moods, Ukrainian civic identity formation at the cognitive, value-emotional and behavioral levels. This public stance can be called "patriotic" or "formed". However, in this group, $22 \%$ of the students chose the response "rather agree" to the statement "If I had the opportunity, I would unhesitatingly move to another country".

Significant differences (according to William H. Kruskal - Wallis criterion) were established in the groups with different types of civic identity $(p \leq 0.05)$ based on all questionnaire scales except «I always defend my rights as a citizen», «I consider myself to be a European», «I consider myself to be a citizen of the world», «I consider myself to be a Soviet person».

Referring to a "Soviet human" category causes complete rejection in all groups of students. So, young people regard the "Soviet identity" category as the opposite pole of the desired identity, a sort of anti-identity.

Interestingly, among those who chose answer 5 - «completely agree» to the statement «I totally identify myself as the citizen of Ukraine» there are students that «completely agree» with the statement «I consider myself to be a European» $(45.5 \%)$ and «I consider myself to be a citizen of the world» $(36.4 \%)$. This confirms our view that the civic identity is a complex phenomenon, and different identities may either «interfere» with each other or "get along», so we can talk about «contradictory/conflicting» or «balanced/holistic» type of civil identity.

We have also established significant differences $(p=0.01)$ in the groups with «protest», «uncertain» and "patriotic» civic identity based on the scales «Overall psychological well-being index» $(\mathrm{Me} 1=17.75, \mathrm{Me} 2=19.96, \mathrm{Me} 3=36.13$, $\mathrm{H}=8.35)$, «Goals in life» $(\mathrm{Me} 1=15.40, \mathrm{Me} 2=21.02, \mathrm{Me} 3=34.88, \mathrm{H}=8.63)$, «Environment management» $(\mathrm{Me} 1=14.85, \mathrm{Me} 2=21.61, \mathrm{Me} 3=32.25, \mathrm{H}=7.02)$, «Conformity» $(\mathrm{Me} 1=11.60, \mathrm{Me} 2=23.11, \mathrm{Me} 3=30.25, \mathrm{H}=9.55)$, «Motivation to success» $(\mathrm{Me} 1=15.00, \mathrm{Me} 2=21.54, \mathrm{Me} 3=32.38, \mathrm{H}=7.21)$, Career orientation «Autonomy» $(\mathrm{Me} 1=28.85, \mathrm{Me} 2=19.52, \mathrm{Me} 3=11.38, \mathrm{H}=8.32)$.

The students from the "protest» group as opposed to the students from the «patriotic» group are not satisfied with themselves and their own lives, do not believe that they can change things for the better, feel helplessness in managing the environment, tend to violate social expectations and norms, do not tend to exert much effort into work and career, are focused on autonomy and independence. For them, the primary task of career development is to be able to work 
independently, to decide independently how, when and what to do to achieve certain goals. For them, career is a method to exercise their freedom.

Conducted factor analysis (Varimax normalized) allowed us to build a 4-factor model that explains $71.6 \%$ of the data variance.

The first model factor (30.2\% of variance) - patriotism - includes scales: "I love Ukraine" (0.826), "I totally identify myself with the citizen of Ukraine" (0.799), "I consider myself to be a patriot of Ukraine" (0.794), «I am proud to be a citizen of Ukraine» (0.777), «It is important to support Ukrainian traditions and culture for me» $(0.770)$, «My idea of myself is closely related to Ukraine» $(0.676)$.

The second factor (16.6\% of variance) - active public stance - includes the scale "I always defend my rights as a citizen of the country" $(0.716)$, «I consider myself to be a European» $(0.624)$, «I consider myself to be a responsible citizen» (0.622), «I appreciate my civic activity» (0.598).

The third factor (13.1\% of variance) - self-fulfillment in the country - includes the scale: "I do not care in which country I will fulfill myself and my talents" $(-0.620)$, "I am ready to work for Ukraine" (0.621), «I believe in the prospects of Ukraine's development as a state» (0.604), "I always take part in the elections" (0.537), "I associate my future only with Ukraine" (0.531), «There are many opportunities for personal and professional fulfillment in Ukraine» (0. 550).

The fourth factor ( $11.7 \%$ of variance) - "anti-sovietic" - includes the scale "I consider myself to be a Soviet person" (-0.841).

Thus, the civic identity in the perception of surveyed students is associated with patriotism, active public stance, opportunity for personal and professional opportunities in own state and «anti-sovietic» (opposite pole of the Ukrainian civic identity).

Using Spearman's rank correlation we established connections between the parameters of the civic identity and psychological characteristics of the students.

We have found connections between the general civic identity parameter and peculiarities of value-motivational sphere of the students (Table 2).

Table 2. Significant correlation connections between the general civic identity parameter and value-motivational sphere parameters

\begin{tabular}{|c|c|c|c|c|c|c|c|c|c|}
\hline & 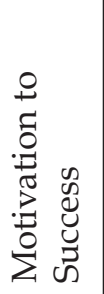 & 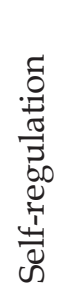 & 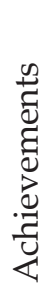 & 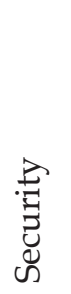 & 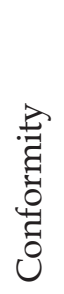 & 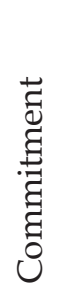 & 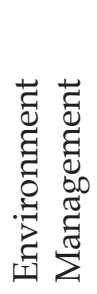 & 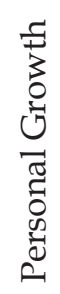 & 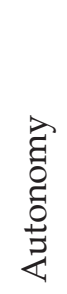 \\
\hline $\begin{array}{l}\text { The general civic } \\
\text { identity parameter }\end{array}$ & 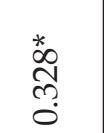 & 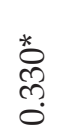 & 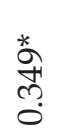 & 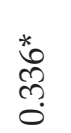 & \begin{tabular}{l} 
* \\
*. \\
\multirow{2}{*}{} \\
0 \\
0
\end{tabular} & 苾 & 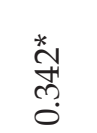 & 炎 & \begin{tabular}{l}
$*$ \\
\multirow{0}{*}{} \\
0 \\
0 \\
0 \\
1
\end{tabular} \\
\hline
\end{tabular}

${ }^{*}-\mathrm{p} \leq 0.05,{ }^{* *}-\mathrm{p} \leq 0.01$.

Source: Own research 
With the growth in the civic identity formation, motivation to success; selfregulation (independence); pursuance of personal success through competence; pursuance of stability, security and harmony of society, family and oneself; limitation of actions and incentives that may harm others or violate social expectations and norms; desire to maintain and improve the well-being of people around; a sense of confidence and competence in the management (the ability to choose and create conditions that meet the personal needs and values) and a sense of continuous self-development (tracking own personal growth and a sense of self-improvement over time, the fulfillment of own potential) increase and focus on autonomy in the career decreases, which provides for disposal of organizational rules and regulations.

Significant correlations between overall psychological well-being parameter and "I believe in the prospects of Ukraine's development as a state" ( $\mathrm{r}$ $=0.358, p \leq 0.05)$, "I am ready to work for Ukraine" $(r=0.362, p \leq 0.05)$ and " $I$ appreciate my public activity" $(\mathrm{r}=0.350, \mathrm{p} \leq 0.05)$ have been found.

With the decrease in the level of psychological well-being of students, pessimism about own prospects for development in the country are increasing, while the desire to be an active citizen is decreasing.

The next stage of the study was to analyze student work on solving 10 problem-oriented situations (incidents) of projective nature to identify different aspects of public stance, formation extent and peculiarities of attitude to Ukrainian civic identity. The method of perception, interpretation and resolution of situations on behalf of a young boy/girl can help identify their unconscious manifestations of identity.

Detailed qualitative analysis of students' works will be presented in the next article. We will provide only one example: "A young guy who has just graduated from a university has two job offers from Ukrainian and foreign companies. In the first case, he is offered a civil servant job with the ability to influence important decisions for Ukraine, in the second case, a foreign company is interested in his professional (intellectual) capabilities for the benefit of the state and therefore proposes to change the place of residence. Which of the two options proposed would you advise the guy to choose?"

$25 \%$ of those with a high level of Ukrainian civic identity formation and conscious level (questionnaire) state their willingness to work for Ukraine, they see opportunities for own professional fulfillment in Ukraine, would not agree to move to another country and associate their future only with Ukraine, on an unconscious level show an inverse picture - they choose the "offer of a foreign company to change job and place of residence". At the same time provide the following arguments: abroad there are "more opportunities for self-fulfillment in the professional sphere", "the best development prospects", "adequate efforts assessment - high salary", "better living conditions, a stable and comfortable life", "the possibility of a better life", "more opportunities to travel, to see something new, meet new culture", etc.

Only $34 \%$ of surveyed students chose Ukraine answering the question "If you had unlimited financial resources, which country would you choose for perma- 
nent residence?". 100\% of the students with the "protest" civic identity did not choose Ukraine as the permanent place of residence, in the "uncertain" group - 72\% of students, and in the "patriots" group - 29\% of students. The most "popular" were countries such as USA, UK, Norway, Switzerland, and Australia.

These are modern emigration sentiments among the surveyed students in the context of the prerequisites of the potential (possible) emigration. It should be noted that the latter does not always lead to leaving the country.

So, we can assume the existence of different types of surveyed student's civic identity, including «protest», «uncertain», «patriotic». The students from the «protest» group as opposed to the students from the «patriotic» group are not satisfied with themselves and their own lives, do not believe that they can change things for the better, feel helplessness in managing the environment, tend to violate social expectations and norms, do not tend to exert much effort into work and career, are focused on autonomy and independence. One of the reasons for the desire to go abroad for permanent residence is the feeling alien and outcast in the native country, poor involvement in social connections and relationships which, in fact, is the daily explication of social identity, particularly civic one. With the decrease in the level of psychological well-being of students, pessimism about their own prospects for development in the country are increasing, while the desire to be an active citizen is decreasing.

Long-term economic crisis, political instability in the country, drop in the living standards are risk factors for emigration and a kind of «test» for patriotic/civic feelings of surveyed students. And, first of all, students indicate insufficient availability of opportunities for self-fulfillment in Ukraine. Opportunities for self-fulfillment, according to the young people, mean a huge range of conditions of different nature: the professional, economic, social, cultural, etc.

It is very important that the country providing the young people with the right to education, contributes to the socio-professional and personal fulfillment of the future experts. It is under these conditions that their civic identification will get emotional and value significance.

\section{CONCLUSIONS}

Civic identity, in our opinion, provides for individual self-identification, on the one hand, as a citizen of the state as society; on the other hand, as a member of the community of citizens. Therefore we can say that civic identity being a personal formation has a "dual nature": on the one hand, corresponds to the group reality, on the other hand - to the organizational reality. This feature civil identity results in the specificity of the scientific analysis and specifies at least two of its planes - organizational-psychological and socio-psychological one (group, relationship). In the first case, we offer to 
analyze the civic identity as a kind of organizational identity (it is important to experiences own relationship with the state, the image of the state (similar to the image of the organization), trust and loyalty); individual's interaction with the state in a variety of instances - state authorities; internalization of standards laid down in the axiological state space, etc.).

In the second case, we need to analyze the civic identity similar to other types of group identity - national, ethnic, etc. It should be noted that the community of citizens is different from the national community, so these concepts are not the same. The nation as a community can live not only in one state; today many great nations also live in the diaspora. Therefore, the nation is united by common language, culture, traditions and identity rather than territory. As for citizen community, they are united primarily as a consortium - a community with common and typical challenges of their lifestyle. They are united by the territory where the laws of a particular state are effective. An important feature of citizen community that affects the civic identity is its referentiality. Under the circumstances of low citizens community referentiality and expressed distrust to the state, there are strong "centrifugal" trends that lead to the desire to lose citizenship of the state, acquire some other citizenship.

An important criterion of the formation and stability of the youth civil identity is its emigration attitudes and orientation. In case of expressed dissatisfaction with the organizational environment of a certain state, a young person develops emigration readiness - readiness to change own civil identity (this also includes internal emigration). Despite all the statements that emigration does not necessarily mean a change of civic identity, we must admit that the willingness to go to another country for permanent residence means inclusion in the organizational environment of a different state, with different legal practice, with different axiological characteristics; activity in this environment over time will inevitably require different civil identity. The presence of common life problems with new fellow citizens (including domestic, economic, legal ones) causes joint search for solutions acceptable to all - hence identity with a new group will be formed and the gradual disactualisation of ties with the previous communities will take place.

Prospects for the further research are seen in the deep psychological study of the construct "civic identity", its typology and its place in the structure of personal identity, as well as analysis of the features of social reality that provoke emigration processes.

\section{REFERENCES}

[1] Abrams, D., \& Hogg, M. A. (1990). An introduction to the social identity approach. In: D. Abrams, M. A. Hogg (Eds.) Social Identity Theory: Constructive and Critical Advances (pp. 1-9) Harvester-Wheatsheaf, London.

[2] Allen, E., \& Seaman, C.A. (2007). Likert Scales and Data Analyses. Quality Progress, 40, 64-65.

[3] Arbyenina, V. (2012). Сутність, прояви та чинники формування громадянської ідентичності українського студентства. Українське студентство у пошуках ідентичності [Essence, mani- 
festation and factors of civic identity of Ukrainian students. Ukrainian students searching for identity]. Kharkiv: V. N. Karazin Kharkiv National University.

[4] Bevz, Т. (2014). Політичні механізми формування громадянської ідентичності в сучасному українському суспільствi [Political mechanisms of civic identity in the modern Ukrainian society]. Kiev: Kuras Institute of Political and Ethnic Studies.

[5] Bezhyna, N. (2013). К вопросу о построении структурной модели гражданской идентичности [On the construction of a structural model of civic identity]. Psychosphere, 2, 8-14.

[6] Boryshevsky, M. (2001). Еталонна модель особистостігромадянина [Reference model of the personality-citizen]. Psychological patterns of development of civic consciousness and self-identity, 1, 39-46.

[7] Deyneko, O., \& Golikov, A. (2012). Еміграційні настрої студентства України. Українське студентство у пошуках ідентичності [Emigration sentiment among the Ukrainian students. Ukrainian students in search for identity]. Kharkiv: V. N. Karazin Kharkiv National University.

[8] Erikson, E. (1968). Identity, youth and crisis. New York: Norton.

[9] Fendrich, J. (1993). Ideal citizens. Albany, NY: State University of New York Press.

[10] Funk, R. (2014). The IFPS's sense of identity and Erich Fromm's legacy. International Forum of Psychoanalysis. 23(2), 74-79.

[11] Hart, D., \& Atkins, R. (2002). Civic competence in urban youth. Applied Developmental Science, $4(6), 227-236$.

[12] Khazratova, N. (2004). Типологічна модель індивідуально-психологічного образу держави [A typological model of the individual psychological state image]. Social psychology, 4, 3-13.

[13] Maurer, T. J., \& Pierce, H. R. (1998). A comparison of Likert scale and traditional measures of self-efficacy. Journal of Applied Psychology, 83, 324-329.

[14] Nasir, N., \& Kirshner, B. (2003). The cultural construction of moral and civic identities. Applied Developmental Science. 7(3), 138-147.

[15] Rovenchak, О. (2011). Особистісна складова ідентичностей і практик українських емігрантів [Personal component of the identities and practices of Ukrainian immigrants]. Social Psychology, 5, 120-130.

[16] Savelyuk, N. (2010). Територіальна прив'язаність як складова громадянської ідентичності особистості: феноменологічний аналіз [The territorial attachment as part of civic identity: phenomenological analysis]. Psychology, 1, 138-144.

[17] Snigur, L. (2003). Моделювання процесу становлення особистості громадянина [Simulation of the citizen identity formation]. Psychology, 21, 3-15.

[18] Sokuryanska, L. (2008). Дефіцит громадянської ідентичності молоді як соціокультурний феномен: чинники актуалізації [The deficit of civic identity of youth as a socio-cultural phenomenon: actualization factors]. Methodology, Theory and Practice of Sociological Analysis of Modern Society, 23 (1), 520-525.

[19] Stegniy, A. (2011). Ukraine and the Eastern Partnership: 'Lost in Translation'. Journal of Communist Studies and Transition Politics, 27 (1), 50-72.

[20] Stepanenko, V. (2002). Етнос-демос-поліс: етнополітичні проблеми соцієтальної трансформації в Україні [Ethnicity-demos-polis: ethno-political challenges of societal transformation in Ukraine]. Sociology: theory, methods, marketing, 2, 102-120.

[21] Tajfel, H., \& Turner, J. C. (1986). The social identity theory of inter-group behavior. In: S. Worchel, \& L. W. Austin (Eds.), Psychology of Intergroup Relations. Chigago: Nelson-Hall.

[22] Vasyutinskyi, V. (2008). Російськомовна спільнота в Україні: загрози ідентичності і постави щодо інтеграції [Russian-speaking community in Ukraine: threat to identity and prospects for integration]. Scientific Bulletin Lviv State University of Internal Affairs. Psychological series, 1, 37-44.

[23] Yates, M., \& Youniss J. (2006). Roots of Civic Identity. International Perspectives on Community Service and Activism in Youth. New York: Cambridge University Press. 